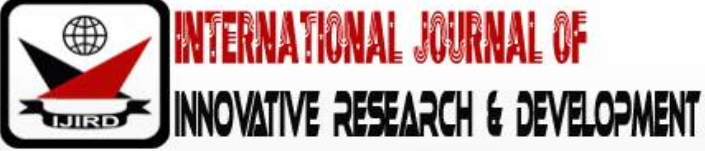

ISSN 2278 - 0211 (Online)

\section{Assessment of Groundwater Potentials in Sedimentary Formation for Domestic Use in Gamawa Local Government Area, Bauchi State, Nigeria}

\author{
AA Adepetu \\ Professor, Department of Geography, Kaduna State University, Nigeria \\ Dr. Aliyu Dadan Garba \\ Senior Lecturer, Department of Geography, Nigerian Defence Academy, Nigeria \\ Emmanuel Sunday Abimiku \\ Lecturer, Department of Geography, Federal University, Gashua, Nigeria
}

\begin{abstract}
:
Variability in geology and hydrogeological conditions have a profound influence on the availability and potential of groundwater across Gamawa area of Bauchi state. Although most part of the study area is underlaid by sedimentary formation, three major hydrogeological units (Keri-Keri, Chad and Recent Alluvium deposit) were identified. Analysis of aquifer Hydraulic Properties' of 10 boreholes were carried out using step-drawdown tests, single stage and recovery measurements to determine transmissivity (T), hydraulic conductivity (K) and specific capacity (Cs). Pumping test data analysis was based on the Cooper-Jacob's (1946) non-equilibrium graphical method. The study shows that aquifers occur at depths of between $25 \mathrm{~m}$ and $84 \mathrm{~m}$ under confined and semi-confined conditions. Yield or discharge (Q) values range from 21$448 \mathrm{~m}^{3} / \mathrm{d}$. The mean discharge value for the ten boreholes is $105.25 \mathrm{~m}^{3} / \mathrm{d}$. The sum of the yield from the ten (10) boreholes is $1052.53 \mathrm{~m} 3 / \mathrm{d}$. This can sustain a population of 42,101 based on water supply standard of 25 litres per day for rural communities (Babatola, 1997). Considering the total population of 8360 people (NPC, 2014) that are currently getting their domestic water from the ten boreholes, in comparison to water supply standard of 25 litre per person per day, this shows that the study area generally has good groundwater potentials in terms of yield. Transmissivity values range from 0.163 to 141.7 $\mathrm{m}^{2} / \mathrm{d}$ with an average of $24.73 \mathrm{~m}^{2} / \mathrm{d}$. These values show proportional variations with yields. However, transmissivity values are not the same across the three hydrogeo logical units in the study area. A relatively higher transmissivity of $141.7 \mathrm{~m}^{2} / \mathrm{d}$ is found within Keri-Keri. Hydraulic conductivity values range from 0.04 to $4.163 \mathrm{~m} /$ day with a mean value of $0.4163 \mathrm{~m} /$ day. The mean hydraulic conductivity value is relatively uniform across all the three hydrogeological units.
\end{abstract}

Keywords: Sedimentary formation, groundwater, Pumping Test, Aquifer, Transmissivity, Gamawa, Bauchi State, Nigeria

\section{Introduction}

Groundwater has proved to be the most reliable resource for meeting rural water demand globally, especially in sub-Saharan where large areas are covered by arid and semi-arid land and permanent river courses are few (MacDonald and Davies, 2000. Groundwater is generally microbiologically uncontaminated and to a certain extent naturally protected from pollution. The resource is relatively cheap to develop, since large surface reservoirs are not required, and water sources can usually be developed close to the demand (UNEP, 1996). Since most of the people in arid and semi-arid areas live in small, scattered villages. The development of water resources in scarcely populated areas with large distances between villages requires efficient organisation, adequate transport facilities and large financial investments. In this regard, groundwater is the preferred water source for small scale supplies in the rural areas.

However, problems arise in areas where communities are underlain by difficult geological conditions, where groundwater resources are limited and hard to find. To have successful and sustainable rural water supply projects it is essential to understand the hydrogeological environment of the project area. In view of this, developing groundwater is generally an excellent option for sustainable water supplies in Gamawa area due to the ephemeral nature of surface water. The large variability in geological and hydrogeological conditions have a profound influence on the availability of groundwater across Gamawa area of Bauchi state of which this study was able to provide an up to date empirical data of the hydrogeology of Gamawa.

\subsection{Description of Study Area}

The study was conducted in Gamawa Local Government Area of Bauchi state, Nigeria. Geographically the Local Government lies between latitude $12.13^{\circ}$ North, longitude $10.54^{\circ}$ East and 397 meters elevation above the sea level. The 
Local Government occupies approximately a total land area of 2,925 km². However, the assessment was limited to ten rural settlements with a total population of 8360 people (NPC, 2014).

\subsection{Climatic and Vegetation Characteristics}

Gamawa's climate is classified as tropical, characterized by alternate wet and dry season. This location is classified as Aw by Köppen and Geiger classification (Abdulkadir, Usman, and Shaba (2015). Generally, the average annual temperature of Gamawa is $34.5^{\circ} \mathrm{C}$ (NIMET, 2014). Gamawa has low rainfall amount, with a mean annual rainfall of 616 $\mathrm{mm}$, and a short rainy season of less than 4 months (NIMET, 2014).

The relative humidity of Gamawa also varies considerably with season. More humid condition is being experienced during the wet season, especially at the peak of the rainy season where relative humidity is as high as $98 \%$ (NIMET, 2014). In Gamawa the mean actual sunshine is 8.8 hours. The sunniest month is November with an average daily sunshine of $9.9 \mathrm{hrs}$ followed by October (9.5 hrs). The month with the lowest amount of sunshine is August (7.3hrs). This may likely be attributed to the rainy season where cloud cover and rain droplets affect the amount of sunshine being received in the area (NIMET, 2014).

The vegetation of Gamawa reflects interactions of climate, soil and, most significantly, disturbance by man. Sahel Savanna covered large parts of the Local Government Area (Bauchi State Civil Service Compendium, 2012). As earlier mentioned, Gamawa is predominantly rural, where groundwater is the main source of water for the inhabitants due to short duration of rainfall ( 3 months) and disperse nature of most settlements.

\subsection{Geology and Hydrogeology}

Most parts of Gamawa is underlain by the Sedimentary Formation of recent to pliocene period. This is characterized by large deposits of alluvium sediments, sand, clay, sandstone and shale. The sedimentary formation as shown in Figure 1 comprises of Alluvial Deposits, Keri-Keri, and Chad hydrogeological units (BSADP, 1988). The Keri-keri formation comprises coarse grained to pebbly sandstone, conglomerates, clayey grit and clays (Offodile, 2014 and Adegoke et al 1986) which was deposited under alluvial, fluvial and marginal lacustrine conditions (Carter et al (1963), Du Preez and Barber, (1965). To buttress on this, Adelana et al, (2008), also stated that Tertiary age Keri-Keri Formation consists of lacustrine or fluvio-lacustrine loosely cemented cross-bedded coarse to fine grained sandstones, with locally occurring claystones, siltstones, ironstones, lignites and conglomerates. It rests uncomfortably on the Gombe sandstone Formation, and thickens towards the centre of the Chad Basin, where it is overlain by the Chad Formation.

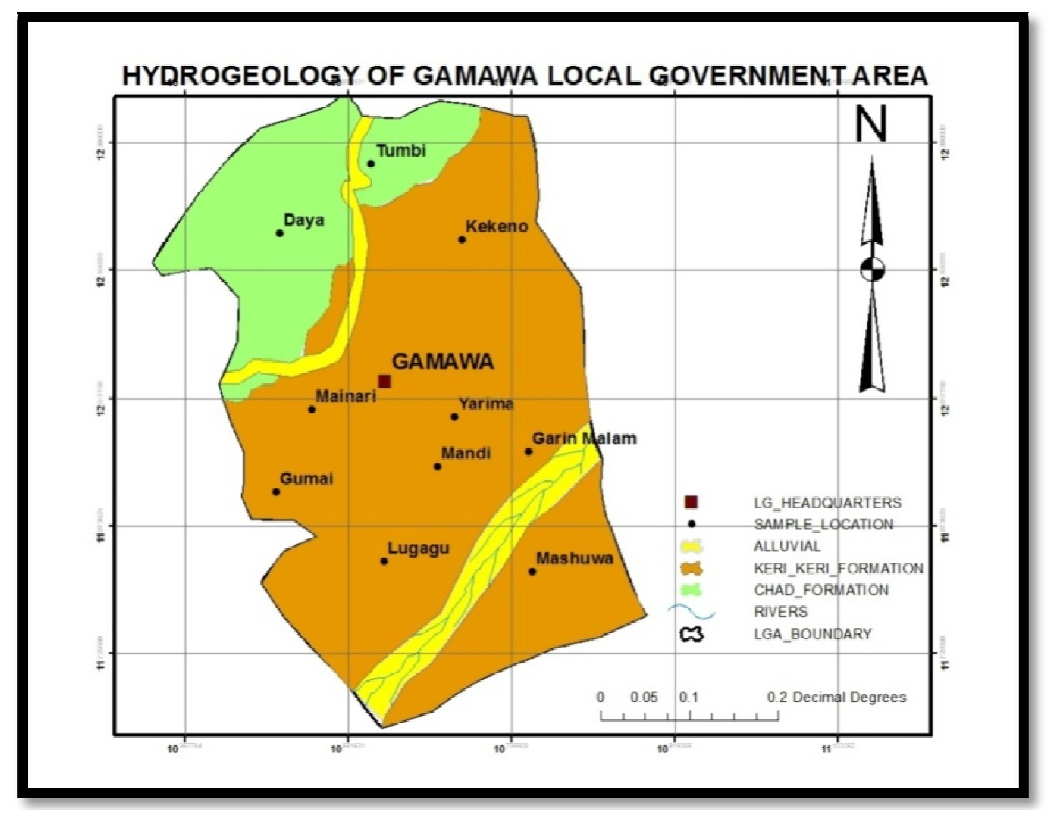

Figure 1: The Hydrogeology Of Gamawa Local Government Area

The dominant lithologies in the Chad Basin, in the northeast of Nigeria, are sandstone, siltstone and shale. The quaternary age Chad Formation is up to $840 \mathrm{~m}$ thick and consists of poorly sorted fine to coarse-grained sand, with sandy clay, clay and diatomite (Adelana et al, 2008). Groundwater is found in the Chad deposits under water table and confined conditions and the yields are very high (BSADP, 1988). The Chad Formation aquifer can be unconfined or confined depending on local conditions. Deeper sandstone layers are often confined and can be artesian. Yield of between 2.5 and $30 \mathrm{l} / \mathrm{s}$ are quoted. The water depth is often between 10 and $15 \mathrm{~m}$ (Offodile, 2002).

The recent alluvium deposits are alluvial deposits along major rivers in Bauchi state which consist of silts clays and sands (BSADP, 1988). Deposits vary in thickness and lithology, with sands, gravels, silt and clay all present in varying proportions. These occur along the main river valleys (Adelana et al. 2008). The recent alluvium deposits are commonly found around Garin Malam and Mashuwa underlain by coarse loose water bearing sands to depth of 6.5 to 8.7 metres. 


\section{Materials and Method}

Pumping test was conducted on ten boreholes within the study area, while the lithology logs of the ten boreholes were obtained from Rural Water and Sanitation Agency (RUWASA). Information on the geological and hydrogeology of Gamawa were obtained from available maps from Bauchi State Agricultural Development Project (BSADP). BSADP defined five hydrogeological units in the state that present fundamental differences in their lithologic and structural conformation (BSADP, 1988). The logs enabled the establishment of the subsurface stratification, casing and screen positions, static water levels and aquifer textural properties while the aquifer pumping test data for each borehole comprised 3 to 4 stage step-drawdown tests, single stage and recovery measurements. These were used to determine aquifer hydraulic properties such as transmissivity (T), hydraulic conductivity (K) and specific capacity (Cs). Pumping test data analysis was based on the Cooper-Jacob's (1946) non-equilibrium graphical method. This method has been found suitable where the abstraction well itself serves as the observation well, as is the case in the present study. By this method, the transmissivity (T) is given by:

$$
\mathrm{T}=\frac{2.303 \mathrm{Q}}{4 \Pi \Delta \mathrm{S}} \cdots \ldots .(1)
$$

Where $\mathrm{Q}=$ discharge or yield $\left(\mathrm{m}^{3} / \mathrm{sec}\right)$.

$\Delta \mathrm{S}=$ change in drawdown over one log cycle.

This formula is useful because some of the boreholes are confined while others are semi-confined. The average drawdown for the ten boreholes is about $8.96 \mathrm{~m}$. The hydraulic conductivity $(\mathrm{K})$ was calculated from

$$
\mathrm{K}=\frac{\mathrm{T}}{\mathrm{b}} \quad \ldots .(2)
$$

Where $\mathrm{T}=\mathrm{as}$ in (1) above

$\mathrm{B}=$ aquifer thickness (equivalent to the total screen length).

The specific capacity (Cs), a measure of well productivity, was computed from:

$$
\mathrm{Cs}=\frac{\mathrm{Q}}{\mathrm{S}}
$$

Where $\mathrm{Q}=$ as in (1) above

$\mathrm{S}=$ maximum drawdown

\section{Results and Discussions}

Bauchi State Agricultural Development Project (BSADP) defined three (3) hydrogeological units in Gamawa area that present fundamental differences in their lithologic and structural conformation to support groundwater management and assessment. The hydrostratigraphic units in the study area are the quartz, silt, sands and clayey of the Chad formation, Kerri -Kerri Formation as well as the recent alluvial deposits around river banks. These constitute the three distinct aquifer units of the area (BSADP, 1988).

From the analysis of borehole lithologs, the study shows that aquifers occur at depths of between $25 \mathrm{~m}$ and $84 \mathrm{~m}$ under confined and semi-confined conditions (See Table 1). Borehole properties in terms of depth, screen intervals (assumed aquifer thickness), static and dynamic water levels, drawdown and yield together with the aquifer constants T, $\mathrm{K}$ and Cs obtained from the Cooper- Jacob methods are presented in Table 1. The Main aquifer within Keri-Keri Formation is laterite at the top of the Keri-keri. Borehole depth, range from $23-60 \mathrm{~m}$. The water levels are often within $12.5 \mathrm{~m}$ of surface. On the other hand, the Recent Alluvial deposits which occupies parts of Garin Malam and Mashuwa area underlain by coarse loose water bearing sands to depth of $31-35.5 \mathrm{~m}$. The water levels are often within $7 \mathrm{~m}$ of surface. The Chad Formation aquifer can be unconfined or confined depending on local conditions. Borehole depth range between $44-82 \mathrm{~m}$. Depth to water level range from $13-20 \mathrm{~m}$.

Yield or discharge (Q) values range from $21-448 \mathrm{~m}^{3} / \mathrm{d}$. The mean discharge value for the ten boreholes is 105.25 $\mathrm{m}^{3} / \mathrm{d}$. Yields are quite high in Tumbi $\left(448.76 \mathrm{~m}^{3} / \mathrm{d}\right)$, which is predominantly Chad Formation. Also, the yield capability of the coarse water bearing alluvial sands around Garin Malam is quite high. The sum of the yield from the ten (10) boreholes is $1052.53 \mathrm{~m}^{3} / \mathrm{d}$.This can sustain a population of 42,101 based on water supply standard of 25 litres per day for rural communities (Babatola, 1997). Considering the total population of 8360 people (NPC, 2014) that are currently getting their domestic water from the ten boreholes, in comparison to water supply standard of 25 litre per person per day, this shows that the study area generally has good groundwater potentials in terms of yield.

Transmissivity is a measure of the capability of the aquifer to transmit groundwater through a one metre wide band over its full depth, under a one metre or unit gradient. Aquifer transmissivity of the boreholes was determined from aquifer pumping tests. From Table 1, transmissivity values range from 0.163 to $141.7 \mathrm{~m}^{2} / \mathrm{d}$ with an average of $24.73 \mathrm{~m}^{2} / \mathrm{d}$. These values show proportional variations with yields. The mean transmissivity value of $24.73 \mathrm{~m}^{2} / \mathrm{d}$ is intermediate and is indicative of withdrawal of local water supply for small communities (Krasny, 1993). However, transmissivity values are not the same across the three hydrogeological units in the study area. A relatively higher transmissivity of $141.7 \mathrm{~m}^{2} / \mathrm{d}$ is found within the Keri-Keri Formation (See Table 1). The Keri-Keri formation has a mean transmissivity value of 30.19 
$\mathrm{m}^{2} / \mathrm{d}$. This is closely followed by the Chad Formation which has a mean transmissivity of $21.6 \mathrm{~m}^{2} / \mathrm{d}$, while the Recent Alluvial Deposits hydrogeological unit has the lowest mean transmissivity value of $11.36 \mathrm{~m}^{2} / \mathrm{d}$ (See Table 2).

Hydraulic conductivity values range from 0.04 to $4.163 \mathrm{~m} /$ day with a mean value of $0.4163 \mathrm{~m} /$ day. The mean hydraulic conductivity value is relatively similar across all the three hydrogeological units (Table 2). The mean hydraulic conductivity value of $0.4163 \mathrm{~m} /$ day is moderate according to classification by Todd (1980) and is typical of clayey sands (Freeze and Cherry, 1979) The specific capacity values range from 11.41 to $431.5 \mathrm{~m}^{2} / \mathrm{d} / \mathrm{m}$ with a mean of $431.5 \mathrm{~m}^{2} / \mathrm{d} / \mathrm{m}$.

\begin{tabular}{|c|c|c|c|c|c|c|c|c|c|c|c|c|c|}
\hline$\frac{z}{\omega}$ & 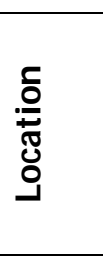 & हี & 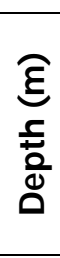 & 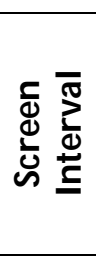 & 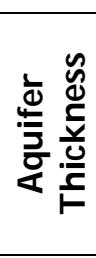 & $\underbrace{g}_{\substack{\xi \\
\xi}}$ & 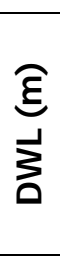 & : & 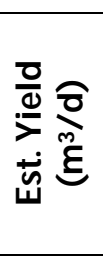 & 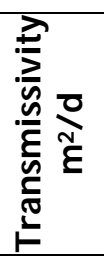 & 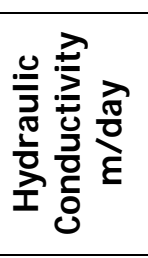 & 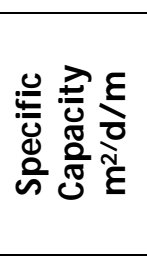 & 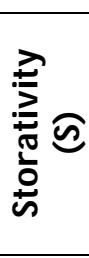 \\
\hline$r$ & 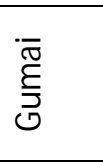 & 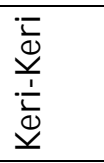 & $\stackrel{\llcorner}{\stackrel{N}{N}}$ & $\begin{array}{l}0 \\
\infty \\
m \\
m \\
m\end{array}$ & $\begin{array}{l}\text { مْ } \\
1\end{array}$ & $a$ & 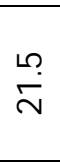 & 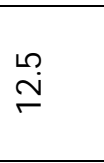 & $\begin{array}{l}\overrightarrow{\hat{n}} \\
\vec{m}\end{array}$ & $\stackrel{\stackrel{L}{N}}{n}$ & $\vec{ન}$ & O্் & $\underset{ت}{\stackrel{-}{-}}$ \\
\hline$N$ & 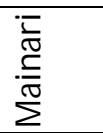 & 它窇 & o & $\stackrel{9}{+}$ & 임 & 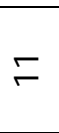 & $\stackrel{\infty}{\stackrel{\infty}{\sim}}$ & $\stackrel{\infty}{\sim}$ & $\begin{array}{l}\overrightarrow{7} \\
\stackrel{7}{0} \\
\stackrel{-}{-1}\end{array}$ & $\stackrel{\widehat{\sim}}{\stackrel{\sim}{N}}$ & $\stackrel{N}{\stackrel{N}{0}}$ & Fै & $\begin{array}{l}\stackrel{5}{\circ} \\
\text { ì }\end{array}$ \\
\hline$m$ & 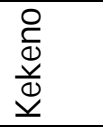 & 岀窇 & กิ & 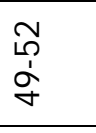 & $\stackrel{\circ}{\dot{m}}$ & ָึ & $\stackrel{\sim}{\stackrel{N}{\sim}}$ & ஸे & $\begin{array}{l}\infty \\
\infty \\
\stackrel{\infty}{=}\end{array}$ & $\begin{array}{l}\tilde{0} \\
\stackrel{-1}{0}\end{array}$ & ठ্ণ & $\begin{array}{l}\text { ○ి } \\
\text { ○ి }\end{array}$ & $\begin{array}{l}\infty \\
\stackrel{\infty}{\sim} \\
\stackrel{\sim}{i}\end{array}$ \\
\hline 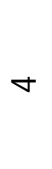 & $\begin{array}{l}: \bar{Z} \\
\sum^{\pi}\end{array}$ & 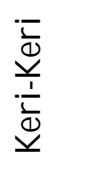 & 8 & $\begin{array}{l}\text { ठิ } \\
\text { ஸे } \\
\text { กิ }\end{array}$ & $\stackrel{\infty}{\infty}$ & $\stackrel{-1}{\stackrel{1}{-}}$ & 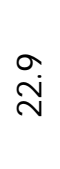 & $\begin{array}{l}\infty \\
1 \\
1\end{array}$ & $\begin{array}{l}\text { N } \\
\stackrel{\text { S }}{\text { N }}\end{array}$ & $\begin{array}{l}\mathscr{L} \\
\text { ले }\end{array}$ & $\stackrel{8}{0}$ & 今ે & @̊ \\
\hline م & 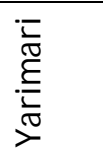 & 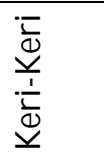 & ిి & 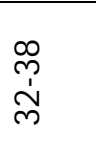 & $\stackrel{0}{0}$ & $\stackrel{+}{\bullet}$ & 㫄 & $\widehat{\widehat{\infty}}$ & $\stackrel{\varphi}{\stackrel{N}{N}}$ & $\underset{+}{\stackrel{H}{+}}$ & Nָ & กิ่ & ฮิ \\
\hline 0 & 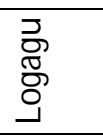 & 秀空 & $\stackrel{\infty}{\not}$ & 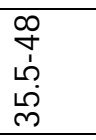 & 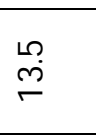 & $\stackrel{\leftrightarrow}{\mathscr{0}}$ & 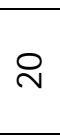 & $\stackrel{\sim}{\oplus}$ & $\begin{array}{l}+1 \\
\oplus \\
\infty\end{array}$ & $\stackrel{\Im}{\exists}$ & 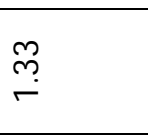 & $\begin{array}{l}\text { กิ } \\
\text { ถึ }\end{array}$ & 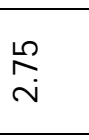 \\
\hline$\wedge$ & 急 & 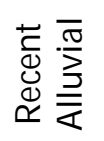 & $\begin{array}{l}\stackrel{\llcorner}{\circ} \\
\stackrel{n}{m}\end{array}$ & $\begin{array}{l}0 \\
\tilde{m} \\
\text { ஸे }\end{array}$ & $\stackrel{\circ}{\rightarrow}$ & $\stackrel{\curvearrowright}{\curvearrowright}$ & $\widehat{\curvearrowright}$ & $\stackrel{0}{\circ}$ & $\begin{array}{l}\infty \\
\infty \\
\stackrel{0}{\exists}\end{array}$ & $\begin{array}{l}\vec{\infty} \\
\vec{\lambda}\end{array}$ & $\begin{array}{l}9 \\
0 \\
0\end{array}$ & $\stackrel{\stackrel{ }{N}}{\stackrel{N}{N}}$ & $\begin{array}{l}\dot{p} \\
\stackrel{p}{+}\end{array}$ \\
\hline$\infty$ & 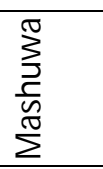 & 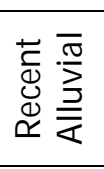 & வே & $\begin{array}{l}\stackrel{\llcorner}{-1} \\
\vec{n} \\
\stackrel{\leftrightarrow}{\omega}\end{array}$ & مٌ مْ & ְִ & $\underset{\infty}{m}$ & $\stackrel{\infty}{-}$ & $\begin{array}{l}m \\
\text { O̊. } \\
\text { in }\end{array}$ & $\vec{\sigma}$ & $\stackrel{\square}{0}$ & $\begin{array}{l}\vec{F} \\
\stackrel{-}{-}\end{array}$ & $\stackrel{\mathscr{m}}{i}$ \\
\hline$\sigma$ & $\begin{array}{l}\overparen{0} \\
\overparen{0}\end{array}$ & 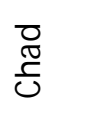 & $\mathscr{F}$ & $\begin{array}{l}\stackrel{2}{m} \\
\text { مे } \\
\text { ते }\end{array}$ & $\stackrel{0}{0}$ & $\stackrel{M}{\rightarrow}$ & $\stackrel{\stackrel{+}{N}}{\stackrel{N}{N}}$ & $\stackrel{\forall}{\circ}$ & $\stackrel{3}{\text { मे }}$ & $\underset{\sigma}{\stackrel{H}{\sigma}}$ & ্ָণ & $\underset{\stackrel{\infty}{+}}{\stackrel{+}{\rightarrow}}$ & $\stackrel{\text { m}}{\rightarrow}$ \\
\hline$\stackrel{0}{\rightarrow}$ & 䔍 & శ్ & § & $\begin{array}{l}\stackrel{+}{1} \\
\text { ஸे }\end{array}$ & $\stackrel{\circ}{\stackrel{\leftrightarrow}{\sigma}}$ & $\begin{array}{l}\infty \\
\stackrel{\leftrightarrow}{0} \\
\stackrel{i}{0}\end{array}$ & $\begin{array}{l}\text { Oे } \\
\text { Oे }\end{array}$ & $\begin{array}{l}\not{H} \\
\stackrel{+}{+} \\
\end{array}$ & $\begin{array}{l}\stackrel{0}{2} \\
\infty \\
\underset{f}{f}\end{array}$ & $\begin{array}{l}\text { N̦ } \\
\stackrel{\text { İ }}{ }\end{array}$ & $\begin{array}{l}8 \\
0 \\
\stackrel{1}{0} \\
0\end{array}$ & جִ & $\stackrel{+}{r}$ \\
\hline & & & جִ & & $\begin{array}{l}10 \\
\infty \\
0 \\
0\end{array}$ & 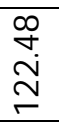 & $\begin{array}{l}\overrightarrow{0} \\
\infty \\
\infty \\
\infty \\
\sigma \\
-1\end{array}$ & 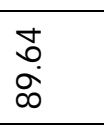 & 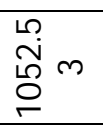 & $\begin{array}{l}\stackrel{L}{N} \\
\stackrel{\leftrightarrow}{N}\end{array}$ & $\begin{array}{l}\mathscr{\Re} \\
\stackrel{7}{+} \\
+\end{array}$ & 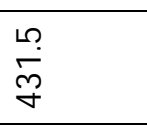 & 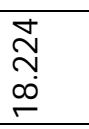 \\
\hline 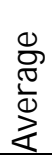 & & & 年 & & $\begin{array}{l}0 \\
\infty \\
0 \\
0\end{array}$ & $\begin{array}{l}\underset{\sim}{\stackrel{1}{*}} \\
\underset{\sim}{\sim}\end{array}$ & $\begin{array}{l}\stackrel{1}{\infty} \\
\infty \\
\infty \\
\stackrel{-}{-1}\end{array}$ & $\begin{array}{l}\text { ठ্' } \\
\varnothing \\
\infty\end{array}$ & 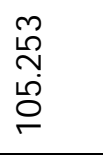 & 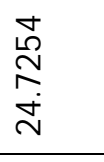 & $\begin{array}{l}\widetilde{6} \\
\stackrel{7}{+} \\
0\end{array}$ & $\begin{array}{l}\stackrel{L}{\sim} \\
\stackrel{9}{\not}\end{array}$ & 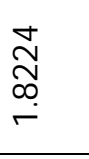 \\
\hline
\end{tabular}

Table 1: Hydraulic Properties of Boreholes in the Study Area 


\begin{tabular}{|c|c|c|c|c|c|c|}
\hline $\begin{array}{c}\text { Hydrogeological } \\
\text { Units }\end{array}$ & $\begin{array}{c}\text { Aquifer } \\
\text { Thickness } \\
(\mathbf{m})\end{array}$ & $\begin{array}{c}\text { Est. } \\
\text { Yield } \\
\left(\mathbf{m}^{3} / \mathbf{d}\right)\end{array}$ & $\begin{array}{c}\text { Transmissivity } \\
\left(\mathrm{m}^{2} / \mathrm{d}\right)\end{array}$ & $\begin{array}{c}\text { Hydraulic } \\
\text { Conductivity } \\
\text { (m/day) }\end{array}$ & Storativity & $\begin{array}{l}\text { Specific Capacity } \\
\mathbf{m}^{2} / \mathbf{d} / \mathbf{m}\end{array}$ \\
\hline Chad Formation & 9 & 245.03 & 21.68 & 0.43 & 4.375 & 273.15 \\
\hline $\begin{array}{c}\text { Keri-Keri } \\
\text { Formation } \\
\end{array}$ & 6.8 & 56.61 & 30.19 & 0.41 & 1.866 & 172.65 \\
\hline Recent Alluvium & 4.8 & 84.42 & 11.36 & 0.42 & 3.395 & 144.34 \\
\hline
\end{tabular}

Table 2: Mean Hydraulic Characteristics Of Aquifers Across Different Hydrogeological Unit

\section{Conclusion}

The hydraulic characteristics of aquifers varies between boreholes and across the different hydrogeological units. While boreholes within the Chad and Keri-Keri formation have intermediate transmissivity, the transmissivity of aquifer within the Recent Alluvium is generally low. However, most of the aquifers have similar hydraulic conductivity, could generally be considered as moderate. The estimated yield of the aquifers varies across the formations. High aquifer yield is found in Chad formation compared to Keri-Keri and Recent Alluvium deposits. The paper shows that the study area generally has good groundwater potentials.

\section{References}

i. Abdulkadir, A., Usman, M. T. and Shaba, A. H. (2015). An Integrated Approach to Delineation of the Ecoclimatic Zones in Northern Nigeria. Journal of Ecology and the Natural Environment.

ii. Adegoke, O.S; Agumanu, A.E; Benkhelil; M.J; Ajayi, P.O. (1986). New stratigraphic, sedimentologic and structural data on the Kerri Formation, Bauchi and Borno States, Nigeria. Jour. Afri. Earth Sci. Vol. 5, pp. 249-277.

iii. Adelana, S.M.A, Olasehinde, P.I, Bale, R.B, Vrbka, P, Edet, A.E and Goni, I.B. (2008). An Overview of the Geology and Hydrogeology of Nigeria. In: Adelana, S.M.A and Macdonald, A.M. Applied Groundwater Studies in Africa. IAH Selected Papers in Hydrogeology Volume 13. Taylor and Francis, London.

iv. Babatola, J. O. (1997). Rural Water Supply: Issues, Problems and Prospects.Water Resources Journal of NAH, 8 (1), 19-25.

v. Bauchi State Agriculture Development Project. (1988). Bauchi State Hydrogeology-Hydrogeological Unit Descriptions by Wardrop Engineering Inc. Winnipeg, Canada, based on 1205 boreholes and 234 boreholes constructed under Contract BSADP-6 and BSADP-19 respectively. Arka Cartographics Limited, Sussex, England.

vi. Bauchi State Civil Service Compendium. (2012). Revitalizing Bauchi State Civil Service: A Compendium on Governor Yuguda's Achievement in Bauchi State Civil Service. Bauchi State Government, Nigeria.

vii. Carter, J.D; Barber, W M.; Tait, E.A. (1963). The Geology of parts of Adamawa, Bauchi and Bornu provinces of North Eastern Nigeria. Geol. Surv. Nig. Bull. 30,180p.

viii. Cooper, H. H and Jacob, C. E. (1946). A Generalized Graphical Method for Evaluating Formation Constants and Summarizing Well-Field History. Trans. Americ. geophysical Union 27. pp 526-534.

ix. Du Preez, JW; Barber, DFM (1965). The distribution and chemical quality of groundwater in Northern Nigeria. Geol. Surv. Nig. Bull. 36, 93p.

x. Freeze, RA; Cherry, JA; (1979). Groundwater. Prentice Hall Inc. 304p.

xi. MacDonald, A.M and Davies, J. (2000). A brief Review of Groundwater for Rural Water Supply in Sub-Saharan Africa BGS Technical Report WC/ 00/ 33.

xii. National Population Commission. (2014). Compendium of Localities in Nigeria. National Population Commission, Abuja, Nigeria.

xiii. Nigerian Meteorological Agency (NIMET). 2014. Numerical Weather Forecast, Bauchi State, Nigeria.

xiv. Offodile, M.E. (2014). Hydrogeology: Groundwater Study and Development in Nigeria. Mecon Geology and Engineering Services Ltd, Jos, Nigeria.

xv. Offodile, M.E. (2002). Groundwater Study and Development in Nigeria. Mecon Services Ltd, Jos, Nigeria.

xvi. Todd, D. 1980.Groundwater Hydrology. John Wiley and Sons Inc New York. 535p.

xvii. United Nations Environment Programme (UNEP). 1996. Groundwater: A Threatened Resource. UNEP, Nairobi (UNEP Environment Library No 15) 